\title{
Romeo and Juliet and Biology
}

\author{
John Maune \\ Hokusei Gakuen University, Junior College English Department, Sapporo, Japan
}

\begin{abstract}
Defining what literature is can be, will and has been, approached from a diverse array of viewpoints. A recent exciting, though neglected or even vilified, view of literature is to take into consideration how literature makes sense in evolutionary terms-literary Darwinism. This concept is used in somewhat reverse fashion for teaching Japanese students studying English as a foreign language. Biological concepts in a content based EFL course are taught using Shakespeare's Romeo and Juliet. The dramatic action can push and stretch our beliefs, but must be true to our human nature. Some examples used in the course include aggression, mate selection (love that is), kin selection, and human universals. As literature itself is a human universal, this leads to a discussion of what is art and why so much time can be spent engaging in art, or how could Shakespeare lead an affluent life nurturing only the abstract, or the stuff that dreams are made on. Defining what literature is can be, will and has been, approached from a diverse array of viewpoints. A recent exciting, though neglected or even vilified, view of literature is to take into consideration how literature makes sense in evolutionary terms-literary Darwinism. This concept is used in somewhat reverse fashion for teaching Japanese students studying English as a foreign language. Biological concepts in a content based EFL course are taught using Shakespeare's Romeo and Juliet. The dramatic action can push and stretch our beliefs, but must be true to our human nature. Some examples used in the course include aggression, mate selection (love that is), kin selection, and human universals. As literature itself is a human universal, this leads to a discussion of what is art and why so much time can be spent engaging in art, or how could Shakespeare lead an affluent life nurturing only the abstract, or the stuff that dreams are made on.
\end{abstract}

Keywords: EFL, evolutionary Darwinism, human universals

\section{Introduction}

Defining literature is a literary exercise that reflects on itself akin to holding up a mirror to a mirror. Possible perspectives abound, which is true too of critical methods of literary interpretation that Marjorie Garber likens to an enfilade - though literary criticism is a volatile field, she is using enfilade to mean a hallway with multiple branching doors - or a mise en abyme - the whole image present in the image itself [1]. She closes her thoughts stating that "literary interpretation, like literature, does not seek answers or closure" and is amenable to "a multiplic ity of persuasive and well-argued meanings."

One such alternate school of literary critique, or translation, merging the humanities and sciencesconsilience as envisioned by E.O. Wilson [2] — is literary Darwinism [3]. Literature is viewed as a mirror held up to nature: human nature. Thus a literary piece can elicit feelings across time and cultures as we all share common ancestors reflected in our heredity. This is not to deny influences of culture, though culture is viewed as an adapted mind that has generated culture as eloquently put forth by Tooby and Cosmides: "culture is the manufactured product of evolved psychological mechanisms in individuals living in groups." [4]. Shakespeare's works span centuries and cultures because of shared innate evolved psychology, though there are many who would take issue with this arguing that his popularity is due more to marketing [5,6], though ironically such marketing for mass manipulation is very dependent on psychological findings contingent upon human nature.

In a course I teach, Shakespeare's Romeo and Juliet is approached with biology in mind. Characters' behaviors are discussed in biological terms that are inherent to humans around the globe, and also across species. Aggression, mate selection (i.e., love), kin selection, parental investment, and human universals, to name a few, are illustrated via examples in the play. This material is used in a two-year EFL program at a Japanese University in a content-based (CB) science course, Life Science, not a literature course. CB courses are used in lieu of standard EFL classes to better engage students with stimulating subject matter. Students must earn $12 \mathrm{CB}$ credits in order to graduate. There are many CB courses from which to choose. Thus, Japanese students in this science course study Romeo and Juliet in English to learn biological concepts. 


\section{Methods}

First students watch Zeffirelli's film version of Romeo and Juliet in its entirety [7], then the party and balcony scenes $(1.5-2.2)$ of Luhrmann's version [8] in English with Japanese subtitles. Text from selected scenes in the play [9], not film scripts, are examined and the film scenes are viewed again.

\section{Application and Interpretation}

The market brawl in the first scene highlights the feud between the two houses. Who is involved? Benvolio enters the scene trying to quell the fight, followed by Tybalt who relishes a fight.

1.1.75-86 (all quotes taken from [9])

[Enter BENVOLIO]

Benvolio. Part, fools!

Put up your swords; you know not what you do.

[Beats down their swords]

[Enter TYBALT]

Tybalt. What, art thou drawn among these heartless hinds?

Turn thee, Benvolio, look upon thy death.

Benvolio. I do but keep the peace: put up thy sword,

Or manage it to part these men with me.

Tybalt. What, drawn, and talk of peace! I hate the word,

As I hate hell, all Montagues, and thee:

Have at thee, coward!

Students then are asked to rank sex and age groups from most to least aggressive. Invariably they assign males in their 20's as the most aggressive. Why are they fighting?

Aggression is further examined in the party scene with Tybalt, pugnacious as ever, fuming over what he perceives as Romeo's inexcusable transgressions.

\subsubsection{6-681}

Tybalt. This, by his voice, should be a Montague.

Fetch me my rapier, boy. What dares the slave

Come hither, cover'd with an antic face,

To fleer and scorn at our solemnity?

Now, by the stock and honour of my kin,

To strike him dead, I hold it not a sin.

Tybalt mentions the stock and honour of his kin as a valid reason to kill Romeo. This leads to discussions of status, reputation, and genetic legacy and the introduction of Napoleon Chagnon's work with the Yanomamo [10]. Chagnon's findings that aggression usually occurred in order to protect or acquire fertile females are introduced. Enhancing status and reputation yields payments in genetic fecundity. At least in Yanomamo society, fierce warriors who had killed enemies in battle fathered more offspring than those who had not. In most modern societies however, a male stressing his value because he killed another man would not be a profitable 
mating strategy. Times, values, and cultures change, but aggressive tendencies still remain highly sex dependent. Though perhaps not common for men to carrier swords and shields in everyday life, Tybalt's actions are easily comprehended.

Aggression is further related to parental investment. Human females invest much more time on offspring than males. Thus the female has to take more care with her reproductive activities. Juliet questions Romeo's intentions when he laments about being unsatisfied in the balcony scene.

\subsubsection{6-977}

Romeo. O, wilt thou leave me so unsatisfied?

Juliet. What satisfaction canst thou have to-night?

He assures her that his meaning was not sexual, though his statement provides dramatic frisson. Simply proposing marriage assures her that his intentions are honorable. The nurse further echoes such concerns.

\subsubsection{0-1325}

but first let me tell ye, if ye should lead her into

a fool's paradise, as they say, it were a very gross

kind of behavior, as they say: for the gentlewoman

is young; and, therefore, if you should deal double

with her, truly it were an ill thing to be offered

to any gentlewoman, and very weak dealing.

Again, Romeo ensures the nurse that he will marry Juliet which satisfies her well. Though written more than 400 years ago, the image of Juliet protecting her chastity until marriage, or a proper pair bonding, would be understood by any Homo sapiens that ever lived, and likely previous Homo species.

Females must be choosy as choosing a sexual partner is much more of a risk than for a male: nine months of labor and years raising a child for a female compared to producing a minuscule amount of semen for a male. A male can leave the child raising to a gullible female, though parental investment varies considerably across species. For animals such as bower birds and seals, males only do contribute their genetic material to their offspring which drives sexual dimorphisms, such as seen for aggression. This then is further supported by examples of species where males invest more in offspring than females leading to complete role reversals. Thus, phalarope - a few species of bird-males are docile and drably colored, and the females are aggressive and brightly colored, and the males choose their mates. Juliet must proceed with caution as Romeo could use her for his a quick sexual liaison which could spread his genes with minimal investment which would benefit him, but would entail dire circumstances for Juliet.

Tybalt also mentions kin which leads to the concept of kin selection [11] widely popularized by Dawkins in his selfish gene theory [12]. Humans, and other animals, behave in ways to best propagate their own genes. People share many of the same genes with their kin, so by helping kin, they help their own genes to proliferate. Tybalt wants to kill Romeo to stand up for his kin, his uncle, and to enhance his reputation as an honourable and stalwart, fierce, man; this is similar to a Yanomamo warrior maintaining his reputation.

Capulet has established power and has no need to prove anything, especially in his own house among his party guests. Furthermore the prince has bound both houses in penalty alike to brawl no more. Capulet does not want to cause a scene.

\subsubsection{8-697}

Capulet. Content thee, gentle coz, let him alone;

He bears him like a portly gentleman; 
And, to say truth, Verona brags of him

To be a virtuous and well-govern'd youth:

I would not for the wealth of all the town

Here in my house do him disparagement:

Therefore be patient, take no note of him:

It is my will, the which if thou respect,

Show a fair presence and put off these frowns,

And ill-beseeming semblance for a feast.

Capulet then asserts he is the man of the house, and forbids Tybalt from disturbing the party. This example is used for introducing human universals, behaviors, such as hospitality, that have been found in all studied human cultures. It may happen, but in no culture is it considered good manners to kill your house guests indiscriminately, or at least such a culture has not been found.

However, breaking and challenging established customs is one of the hallmarks of literature; normal and mundane are not conducive to literary success - conflict piques our interest [14, 15]. Falling in love is normal, while falling in love with your greatest sworn enemy is not, though of course it is possible and quite dramatic. Petrarchan-style love gave the lady time to test her lover's true intentions as is the case in the source material that Shakespeare adapted his play from: The Tragicall Historye of Romeus and Juliet by Brooke. However, Shakespeare altered his plot in many significant ways. Shakespeare was adept at knowing his audiences' stops and playing upon them stretching the bounds of believability, but not breaking them.

Juliet declaring her love for Romeo while unbeknownst to her he is hiding in the bushes is one such addition that fuels our emotional involvement. Professing your love to someone is part of the mating process, but the male is usually the one initiating things, and with the desired partner knowingly part of the process. It is somewhat humorous or uncomfortable to watch Juliet declaring her love for Romeo in what she thinks is private counsel only for him to pop out and take her at her word. It is innately felt to be out of sorts and we feel for her error.

This conflict with the accepted patterns of wooing or mating is one of many conflicts or dramatic hooks that pull the reader into the narrative. Newly happily married Juliet: learns that her husband has killed her cousin and is banished, is promised to Paris by her father, disobeys her father, is told by her closest confidant, the nurse, to forsake Romeo and marry Paris, consents to marry Paris, appears the die, is buried and mourned over, is reborn, and finally dies for real. Shakespeare amped the pace having the of dramatic reversals take place over a frenzied five days. The drastic reversals of fortune were readily employed by Shakespeare throughout his plays, and were recognized by Aristotle as vital to tragedy which he termed peripeteia [16] and much later as topsy-turvy by Bakhtin as part of the carnivalesque [17].

The discussion of Shakespeare and biology leads to questions of why art in its many forms is a human universal. Shakespeare made a very good living writing poetry and plays - though he had to be creative to secure an income as previous playwrights made little money from their craft [18]. Why art is pursued at all by humans is a question that needs to be asked, especially when studying behaviors based on driving biological needs. Do you need Shakespeare? I have spent much time and money to watch and read his plays, but why, whether it be Shakespeare, Dr. Seuss, or any other print media (my five year old daughter loves to have Spider-Man stories read to her), are humans are drawn to literature or narrative? A wide range of possibilities for our literary bent are discussed [19, 20,21, 16, 22, 23], however there is no closure or a literal answer.

My use of Romeo and Juliet to highlight biological concepts is not just a teaching method for CB EFL lessons. Though arsy varsy in approach, it is also a reaction to the academy tuning its back on literary Darwinism and consilience to keep science out of the humanities. Maintaining the science war confrontational stance between the humanities and sciences denies what literary Darwinism can contribute to our understanding of literature. Taking into account the biology behind dramatic action is but another path to discern meaning that can further enhance understanding of stylistic methods in line with the continuing evolution of literary interpretation suggested by Garber where closure is not possible due to "the richness and fecundity of both the reading and writing process." [1]. 


\section{References}

[1] M. G. Garber, The Use and Abuse of Literature, New York, USA: Pantheon, 2011, ch. 9, pp. 282-3.

[2] E. O. Wilson, Consilience: The Unity of Knowledge, New York, USA: Knopf, 1998.

[3] J. Carroll, Reading Human Nature: Literary Darwinism in Theory, New York, USA: State University of New York Press, 2011.

[4] J. Tooby and L. Cosmides, "The Psychological Foundations of Culture," in The Adapted Mind: Evolutionary Psychology and the Generation of Culture, J. Barkow, L. Cosmides and J. Tooby, Eds., Oxford, UK: Oxford University Press, 1992, ch 1, p. 24.

[5] S. Greenblatt, S., Renaissance Self-fashioning, from More to Shakespeare, Chicago, USA: University of Chicago Press, 1980.

[6] G. Taylor, Reinventing Shakespeare: A Cultural History from the Restoration to the Present, Oxford, UK: Oxford University Press, 1991.

[7] J. Brabourne and A. Havelock-Allen, A. (Producers), and F. Zeffirelli (Director), Romeo and Juliet [Motion picture], United Kingdom: Paramount Pictures, 1968.

[8] B. Luhrmann and G. Martinellis, G. (Producers), and B. Luhrmann (Director), Romeo and Juliet [Motion picture], United States: 20th Century Fox, 1996.

[9] W. Shakespeare, The Unabridged William Shakespeare [Globe Edition], W. G. Clark and W. A. Wright, Eds. Philadelphia, USA: Courage Books, 1911. Available: http://www.opensourceshakespeare.org/

[10] N. Chagnon, Yạnomamö: The Fierce People, New York, USA: Holt, Rinehart and Winston, 1968.

[11] W. D. Hamilton, “The genetical evolution of social behaviour," Journal of Theoretical Biology, vol. 7, pp. 1-52, 1964. https://doi.org/10.1016/0022-5193(64)90038-4

[12] R. Dawkins, The Selfish Gene, Oxford, UK: Oxford University Press, 1976.

[13] D. E. Brown, Human Universals, New York, USA: McGraw-Hill, 1991.

[14] B. Boyd, On the Origin of Stories : Evolution, Cognition, and Fiction, Cambridge, USA: Harvard University Press, 2009.

[15] J. Gottschall, The Storytelling Animal: How Stories Make Us Human, Boston, USA: Houghton Mifflin Harcourt, 2012.

[16] S. Halliwell and Aristotle. Aristotle's Poetics. Chicago, USA: University of Chicago Press, 1998.

[17] M. Bakhtin, M., Rabelais and His World, H. Iswolsky trans, Bloomington, USA: Indiana University Press, 1984.

[18] J. Bate, The Genius of Shakespeare, Oxford, UK: Oxford University Press, 2008, ch 1, pp. 16-22.

[19] S. Pinker, How the Mind Works, New York, USA: W. W. Norton, 1998.

[20] J. Carroll, "Steven Pinker's cheesecake for the mind," Philosophy and Literature, vol. 22, pp. 478-485, 1998 https://doi.org/10.1353/phl.1998.0036

[21] G. Miller, The Mating Mind: How Sexual Choice Shaped the Evolution of Human Nature, London, UK: Vintage, 2000.

[22] D. Barash, Homo Mysterious: Evolutionary Puzzles of Human Nature, Oxford, UK: Oxford University Press, 2012.

[23] E. Dissanayake, Art and Intimacy: How the Arts Began, Seattle, USA: University of Washington Press, 2012. 